\title{
A SORDÉLY (Emberiza calandra) ÉLŐHELYVÁLASZTÁSÁNAK VIZSGÁLATA A MOSONI-SÍKON
}

\author{
Varga Szabolcs, Kelemen Petra, Csiszár Ágnes \& Winkler Dániel \\ Soproni Egyetem, Vadgazdálkodási és Gerinces Állattani Intézet \\ University of Sopron, Institute of Wildlife Management and Vertebrate Zoology \\ H-9400 Sopron, Bajcsy-Zs u. 4., Hungary \\ e-mail:vszab1944@gmail.com; kelemen13@gmail.com; csiszar.agnes@uni-sopron.hu; \\ winkler.daniel@uni-sopron.hu
}

\begin{abstract}
VARGa SZ., Kelemen P., CSISZÁr Á. \& WinkLer D.: HABITAT SELECTION OF THE CORN BUNTING (Emberiza calandra) IN THE MOSONI-PLAIN. Hungarian Small Game Bulletin 13: 125-141. http://dx.doi.org/10.17243/mavk.2017.125

The main goal of research was to survey the population of Corn Bunting (Emberiza calandra) in the area of the MOSON Project. Further aim was to study the habitat selection of the Corn Bunting by surveying the plant species richness and diversity, the vegetation structure and the food availability of the Corn Bunting territories compared with randomly generated and surveyed control plots in the same area.

A total of 18 pairs of Corn Bunting were recorded in the 880 ha area, which equals to a breeding density of 0,21 pairs $/ 10$ ha. The birds preferred the grassy edges with occasional presence of shrub and tree species (Rosa canina, Sambucus nigra, Ulmus minor), meaning that vegetation height diversity plays an important role in habitat selection of Corn Bunting.

Regarding floristic composition, hierarchical cluster analysis based on the Bray-Curtis index showed a clear separation between the Corn Bunting territories and the control plots. For what food availability concern, apart for the increased weed species diversity in the edges, insectivorous food preferred by Corn Bunting (like spiders, bugs) showed an accumulation in the edges, which also explains the grassy edge habitat preference of the studied species.
\end{abstract}

KULCSZAVAK: sordély, élőhely, agrárintenzifikáció, szegély ökotonok

KEY WORDS: Corn Bunting, habitat, agricultural intensification, edge ecotones

\section{BEVEZETÉS}

A mezőgazdálkodás fokozatos térhódítása a természetes élőhelyek, a biodiverzitás csökkenéséhez vezetett (BENTON et al., 2003). Ezekhez az új, mesterséges élőhelyekhez kezdetben az élővilág viszonylag jól tudott alkalmazkodni, azonban a XX. század második felétől jellemző, egyre növekvő mezőgazdasági intenzifikációval a mezei életközösségek már nem tudtak lépést tartani (SUTHERLAND, 2002). Eleinte a változásokra érzékenyebb fajok tüntek el vagy csökkent jelentősen denzitásuk. A természetvédelem kezdetben csak ezekre a ritka fajokra összpontosított, az elmúlt évtizedekben azonban az ún. gyakori fajok egyedszáma is drasztikus csökkenésnek indult Európa szerte (INGER et al., 2015). Ilyen madárfajnak számít többek között a mezei pacsirta (Alauda arvensis), a tövisszúró gébics (Lanius collurio), a citromsármány (Emberiza citrinella) és a sordély (E. calandra) (1. ábra) is. A növekvő intenzifikálódás egyre több fajra kiterjedő negatív hatását először a nyugat-európai államokban pl. Nagy-Britannia, Hollandia, Franciaország, Dánia - ismerték fel, mivel itt hosszabb időn 
keresztül folyt a nagyüzemi jellegü mezőgazdálkodás, mint Közép- és Kelet-Európa országaiban. A volt szocialista országokban a rendszerváltást követő időszakban újra az extenzív jellegü gazdálkodás került előtérbe, ezért ezekben az államokban - így Magyarországon is - kedvezöbbek a körülmények (VERHULST et al., 2004). Az utóbbi években végzett kutatások eredményei aggodalomra adnak okot, ugyanis kimutatták, hogy az intenzíven müvelt területeken az említett énekesmadárfajok hazai populációknál is megfigyelhetők negatív változások (ERDŐs et al., 2007; KovÁCs et al., 2007).

A sordélyt ma az agrárélőhelyek egyik indikátorfajaként tartják számon (WATSON et al., 2007). Európai állományát 7,9-22 millió párra becsülik, legjelentősebb állományai Spanyolországban, Törökországban és Lengyelországban találhatóak (BIRDLIFE INTERNATIONAL, 2014). Hazánkban általánosan elterjedt faj, elsősorban a sík- és dombvidéki területeket kedveli, de kisebb számban a hegyvidékeken is megtalálható, 400 méter tengerszint feletti magasságig (MÁRKUS, 1998). Hazai állománynagysága 165 000-225000 párra tehető (MME NOMENCLATOR BIZOTTSÁG, 2008).

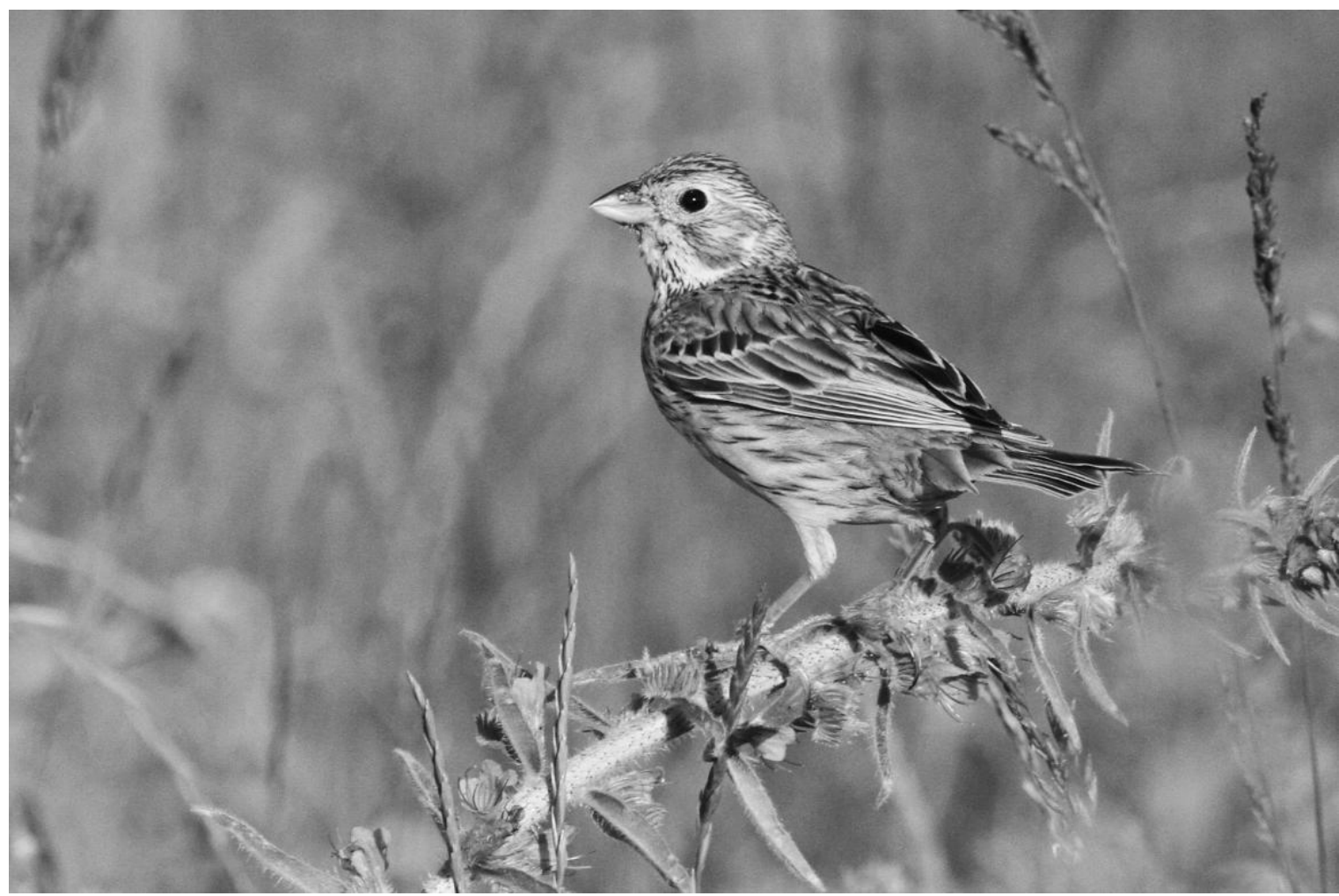

1. ábra: Sordély (Fotó: Winkler D.)

Figure 1: Corn Bunting (Photo: D. Winkler)

A sordéllyal foglalkozó külföldi szakirodalom rendkívül bőségesnek mondható (pl. Donald \& Evans, 1995, Donald \& Aebischer, 1997, StoAte et al., 2000, Perkins et al., 2011, 2013). A csekély számú hazai publikáció (SCHENK, 1930, BÁrSONY, 1934, 1955, AMBRUS, 1997) elsősorban faunisztikai és költésbiológiai megfigyeléseket közöl, a faj élőhelyválasztásával azonban kevesen foglalkoztak. Munkánk fó célkitüzése a sordély állományfelmérése és élőhelyválasztásának vizsgálata volt extenzív agrárkörnyezetben, a Kisalföld északi részén található MOSON Project területén. További célunk volt a sordély territóriumok botanikai értékelése, valamint a táplálékkínálat felmérése. 


\section{ANYAG ÉS MÓDSZER}

\subsection{VIZSGÁLATI TERÜLET}

A MOSON Project mintegy 880 ha kiterjedésü területe a Kisalföldön, a Mosoni-sík kistájon helyezkedik el. A táj arculatát napjainkban a szántóföldi növénytermesztés határozza meg, mivel a termőhelyi tényezők kiválóak a mezőgazdasági termelés számára (DövÉNYI, 2010). A mezőgazdálkodás térhódításával a természetes erdő- és gyepterületek elenyésző kiterjedésü, erősen fragmentált foltokban találhatók csak meg. Az intenzív mezőgazdasági tevékenység oly mértékü negatív hatást gyakorolt a természetes mezei életközösségekre, amely számos élőhely- és fajvédelmi program életre hívását tette szükségessé.

A MOSON Project célja, hogy minél kedvezőbb feltételeket biztosítson a mezei élettérhez kötődő állatfajok számára a gazdálkodás folytatása mellett is, kiemelt figyelmet fordítva a túzokra (Otis tarda) és a fogolyra (Perdix perdix). A területen ún. vándorlósávos müvelést folytatnak, amelynek lényege, hogy az ugar és az extenzíven müvelt területeket 1-5 éves különbséggel váltogatják. A szántókon a legnagyobb arányú termesztett növény az őszi búza (Triticum aestivum), de viszonylag nagy területen folyik a repce (Brassica napus) termesztése is, ami a túzok számára kedvező. Ezen kívül nagyszámban megtalálhatóak az ún. túzokföldek is, amelyek a Mosoni-síkra jellemző, ugar jellegü területek (FARAGÓ, 2006).

\subsection{TEREPI FELMÉRÉSI MÓDSZEREK}

\subsubsection{A sordély állományfelmérése}

A sordélyok állományfelmérésére április elejétől május végéig került sor, ez nagyjából lefedi a faj első költésének idejét. A felmérés során összesen 4 alkalommal jártuk be a területet (2015. április 25., május 7., 16., 26.), térképen jelölve a jellegzetesen kiülöhelyeken éneklő sordélyokat. A felméréseket reggel 6 órától délelőtt 10 óráig végeztük, csapadék és szélmentes napokon. A felmérést megkönnyítette a faj jellegzetes, erős éneke. Az akusztikus észlelést követően távcső segítségével behatároltuk a madár pontos helyét, majd bemértük a kiülőhelyek koordinátáit. A biztos kiülőhelyeket - amelyen a madarat legalább 3 felmérés során megfigyeltünk - praktikusan a territórium középpontjának tekintettünk.

A felmért territóriumokból összesen 8-at választottunk ki további vizsgálatokra (botanikai felvételezést, táplálékkínálatra irányuló vizsgálatok). A tényleges territóriumok (SOR) mellett random pont generáló függvény (Hawth's Analysis Tools for ArcGIS - Beyer 2004) segítségével kijelölt, ugyancsak 8 kontrollpont (KTR) esetében is elvégeztük a botanikai és az ízeltlábú táplálékkínálat vizsgálatokat.

\subsubsection{Botanikai felvételezés}

A botanikai felvételezés során a sordély élöhelyek, valamint a kontrollpontok növényzetét transzektek mentén vizsgáltuk. Minden egyes éneklőpont és kontrollpont körül 50 m sugarú körben ( $\sim$,8ha területü terrirórium) három, 50 méteres transzektet fektetünk le, a sordély által használt szegélyekkel párhuzamosan (2. ábra).

Mivel ezek az élőhelyek többnyire utak vagy más vonalas létesítmények mentén helyezkedtek el, a két transzketet az út azon oldalán helyeztük el, ahol a sordélyt észleltük, a 
harmadikat pedig az út másik oldalán, az utat közvetlenül szegélyező növényzetben. Az út azonos oldalán található transzektek közötti távolság $20 \mathrm{~m}$ volt, mivel megfigyeléseink szerint a madár elsősorban a szegélyeket használja. Az 1 méter széles, 50 méter hosszú transzektek felvételezése Braun-Blanquet-módszerrel (1928) történt, az abundancia - dominancia viszonyok jellemzésére 7-fokozatú egyszerüsített skálát használtunk. A növényfajok meghatározása az Új Magyar Füvészkönyv (KIRÁLY, 2009) felhasználásával történt. A felvételek feldolgozása során a fajokhoz a Flóraadatbázis 1.2 taxon listájának (HORVÁTH et al., 1995) felhasználásával hozzárendeltük a Borhidi féle szociális magatartás típusokat (BORHIDI, 1993), valamint KIRÁLY (2009) munkája alapján képzett átlagos magasságukat.

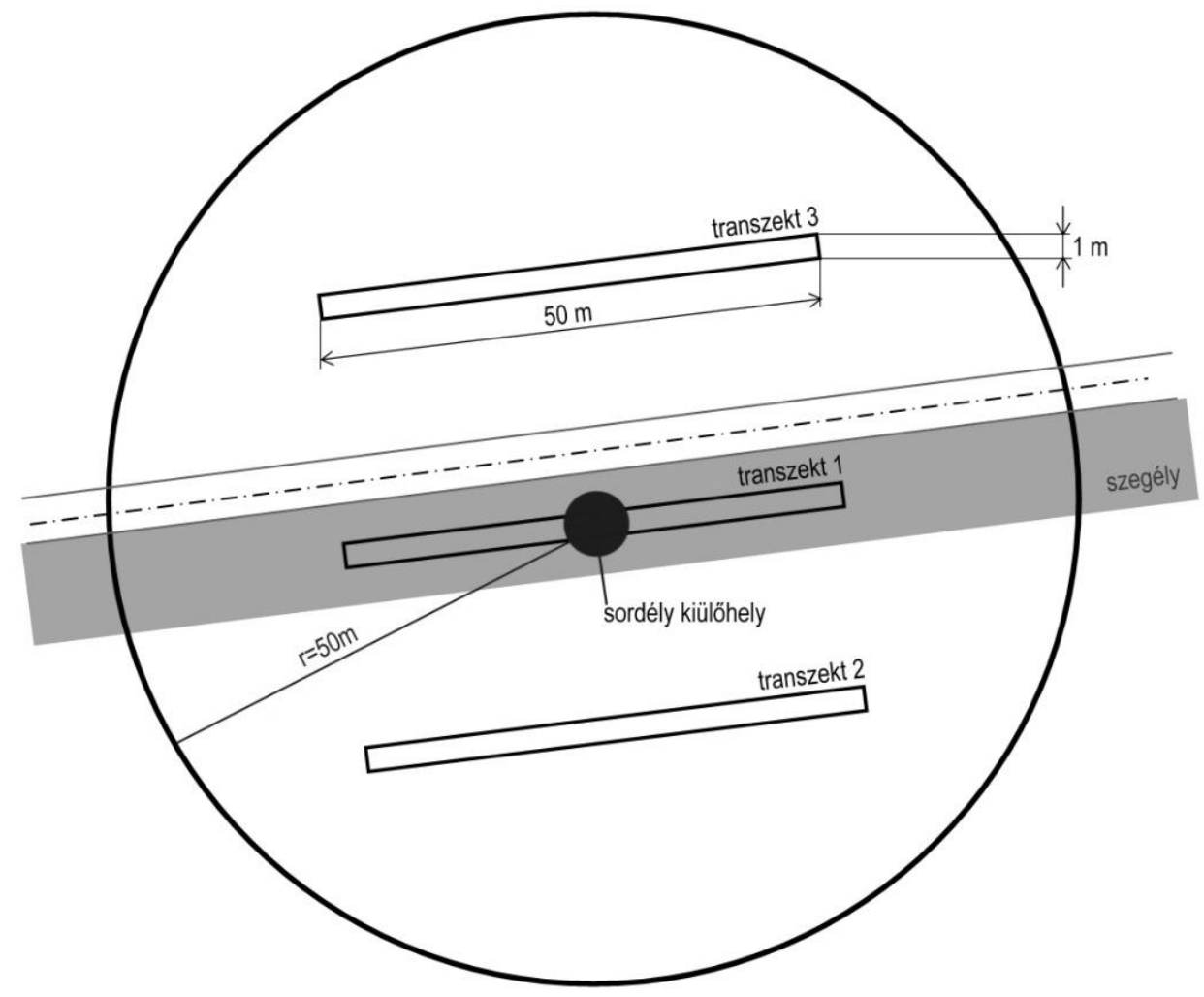

2. ábra: A botanikai felvételezés sémája

Figure 2: Scheme of the botanical survey

\subsubsection{Az állati eredetü táplálékkínálat felmérése}

A sordély táplálkozása rendkívül változatos. A növényi magvak (gabonafélék, gyommagvak) mellett állati eredetü táplálékot (pókok, ezerlábúak, egyenesszárnyúak, félfedelesszárnyúak, lepkehernyók, csigák, férgek) is fogyaszt, ami különösen a költési időszakban jelentős, sőt, a legtöbb magevő madárhoz képest kimagasló a rovarfogyasztása (GLUTZ VON BLOTZHEIM \& BAUER, 1997, MÁRKUS, 1998). A faj változatos táplálkozását figyelembe véve az állati eredetü táplálékkínálatot kétféle módszerrel is vizsgáltuk mindegyik minta és kontrollterületen. 


\subsubsection{Barber-féle talajcsapda}

A talajfelszíni ízeltlábú (Arthropoda) fauna gyüjtéséhez Barber-féle talajcsapdát használtunk, amely a talajlakó, talaj felszínén vadászó-táplálkozó (fissurbiontok) állatcsoportok felmérésére leginkább alkalmas, a nemzetközi gyakorlatban is elfogadott módszer (KÁDÁR et al., 2006). Az alkalmazott csapdák $6,5 \mathrm{~cm}$ átméröjü, 300 milliliteres müanyagpoharak voltak, amelyeket a földbe ástunk úgy, hogy a talajfelszínnel egy szinten legyenek. Ölőfolyadék $70 \%$ etilén-glikolt használtunk. A nagyobb testü gerincesek (kisemlösök, madarak) megóvására félgömb alakú dróthálót rögzítettünk a csapda fölé. Minden mintavételi helyen transzektenként (1. ábra) 3-3 talajcsapda müködött május és június hónapokban 2 hetes intervallumokban. A gyüjtött anyagot föbb taxononk szintjén határoztuk meg. Ezt 24 órás szárítás követte $85-90{ }^{\circ} \mathrm{C}$-on, majd a száraz biomassza mérése.

\subsubsection{Rovarszívó}

A növényzeten előforduló ízeltlábú fauna vizsgálatához rovarszívót alkalmaztunk. Vizsgálatunk során egy átalakított lombszívót használtunk, amely müködése megegyezik az ismert rovarszívókéval (pl.: D-vac). A módszer gyors és rövid idő alatt nagyszámú minta vételére alkalmas. A beszívott állatok egy szövetzsákba kerültek, majd a mintákat 70\%-os etil-alkoholban konzerváltuk. A vizsgálatot május végén végeztük 3 transzektben, a 2. ábrán megadott sémát követve.

\subsection{AZ ADATFELDOLGOZÁS ÉS KIÉRTÉKELÉS MÓDSZEREI}

A többváltozós elemzésekhez összesen 9, az élöhely növényzetére, valamint a táplálékkínálatra vonatkozó paramétert számszerüsítettünk (1. táblázat). A foltosság (Pacth) egy arányszám, amely a jól elkülönülö, magasabb növényfoltok, cserje- és facsoportok területének illetve az azokhoz tartozó szegélyhosszaknak az aránya. Mérését nagy felbontású légifotón végeztük.

1. táblázat: Az élőhelyet leíró jellemzők adatrendszere

Table 1: List of habitat variables

\begin{tabular}{lc}
\hline \multicolumn{1}{c}{$\begin{array}{c}\text { Az adatrendszer komponensei } \\
\text { habitat variables }\end{array}$} & $\begin{array}{c}\text { Jelölés az elemzés során } \\
\text { abbreviations }\end{array}$ \\
\hline növényzet fajszáma - plant species richness & PL_S \\
növényzet diverzitása (Shannon) - plant diversity & PL_Div \\
növényzet természetessége (sensu Borhidi) - plant naturalness value & PL_Nat \\
növényzet magassági diverzitása - plant heigh diversity & PL_HDiv \\
foltosság - patchiness & Pacth \\
ízeltlábú táplálék egyedszám (Barber csapda) - arthropod number (Barber) & F_NBar \\
ízeltlábú táplálék tömeg (Barber csapda) - arthropod mass (Barber) & F_WBar \\
ízeltlábú táplálék egyedszám (rovarszívó) - arthropod number (D-vac) & F_NVac \\
ízeltlábú táplálék tömeg (rovarszívó) - arthropod mass (D-vac) & F_WVac \\
\hline
\end{tabular}

A statisztikai elemzéseket a Past programcsomag (HAMMER et al., 2001) és az SPSS statisztikai program (NIE et al., 1975) segítségével végeztük. 


\subsubsection{Hasonlósági elemzés}

A tényleges sordély territóriumok és kontrollterületek növényzetének hasonlóságát a Jaccard index (JACCARD, 1901) és a Bray-Curtis index (BRAY \& CURTIS, 1957) segítségével vizsgáltuk. Előbbi csak az egyes fajok jelenlét-hiányát veszi figyelembe, míg utóbbi előnye, hogy a mennyiségi viszonyokat is figyelembe veszi.

$$
J a=\frac{c}{a+b+c} * 100 \quad \text { (Jaccard) }
$$

ahol: $\quad c$ : a két cönózis közös fajainak száma $a$ és $b$ : csak az $a$ ill. $b$ cönózisban előforduló fajok száma

$$
C_{B C}=\frac{\sum_{i=1}^{S}\left(n_{1 i}, n_{2 i}\right)}{\sum_{i=1}^{S}\left(n_{1 i}+n_{2 i}\right)} \quad \text { (Bray-Curtis) }
$$

ahol: $\quad S$ : fajszám

$n_{1 i}$ : i-edik faj egyedszáma az $1 \mathrm{sz}$. cönózisbam

$n_{2 i}:$ i-edik faj egyedszáma az $2 \mathrm{sz}$. cönózisbam

Klasszifikációs eljárásként hierarchikus agglomeratív cluster analízist végeztünk a Jaccard és a Bray-Curtis indexek alapján (MICHIE, 1982).

\subsubsection{Főkomponens analízis}

A felmért territóriumok és a kontrollpontok alapján, a sordély habitat-preferencia összefüggéseinek feltárásához a felmért vegetáció és táplálékkínálat jellemzők értékeiből összeállított adatrendszerre főkomponens analízist (PCA) végeztünk. A főkomponens analízis egy olyan többváltozós statisztikai eljárás, amely során az eredeti nagyszámú, egymással többé-kevésbé korreláló változókat lineárisan transzformáljuk redukált számú, egymástól független változók halmazába. Az analízist az SPSS statisztikai program segítségével végeztük el (SPSS, 1999). Az SPSS algoritmusa a fökomponenseket a maximum variancia kritérium alapján határozza meg olyan módon, hogy a hozzájuk tartozó sajátértékek alapján sorba is rendezi. Az algoritmusok általában az egynél nagyobb sajátértékü komponenseket számítják ki és veszik be a további analízisbe.

\section{EREDMÉNYEK}

\subsection{SORDÉLY TERRITÓRIUMOK}

A vizsgálati időszak alatt összesen 18 biztos sordély territóriumot sikerült felmérni, amelyek kivétel nélkül szegélyélőhelyekben voltak megtalálhatók. Az összes beazonosított territóriumot, valamint a további vizsgálatokhoz random kiválasztott 8 territóriumot és 8 kontrollpontot az 1. térkép szemlélteti.

A MOSON Project területén a leggyakoribb sordély kiülőhelyeket a táblaszegélyek magasra növő lágyszárú fajai jelentik, ezekre példa a terjőke kígyószisz (Echium vulgare), útszéli 
bogáncs (Carduus acanthoides), szöszös ökörfarkkóró (Verbascum phlomoides) közönséges aszat (Cirsium vulgare), ebnyelvü fü (Cynoglossum officinale). Több alkalommal figyeltünk meg éneklő sordélyokat fa- és cserjefajokon is, ilyenek a fehér akác (Robinia pseudoacacia), a mezei szil (Ulmus minor), a fekete bodza (Sambucus nigra) és a gyepürózsa (Rosa canina). Ezen kívül különböző mütárgyak (magasles, mérföldkő) is többször szolgáltak kiülőhelyül.

A sordély territóriumok közös jellemzője, hogy a rajtuk megjelenő változatos fajkészlet mellett is általában három-négy faj dominanciájával jellemezhetők. A domináns növényfajok a vetett gyepek, illetve parlagterületek jellegéből adódóan gyakran a pázsitfüvek közül kerültek ki, emellett csak néhány kétszikü faj ért el jelentős borítást.

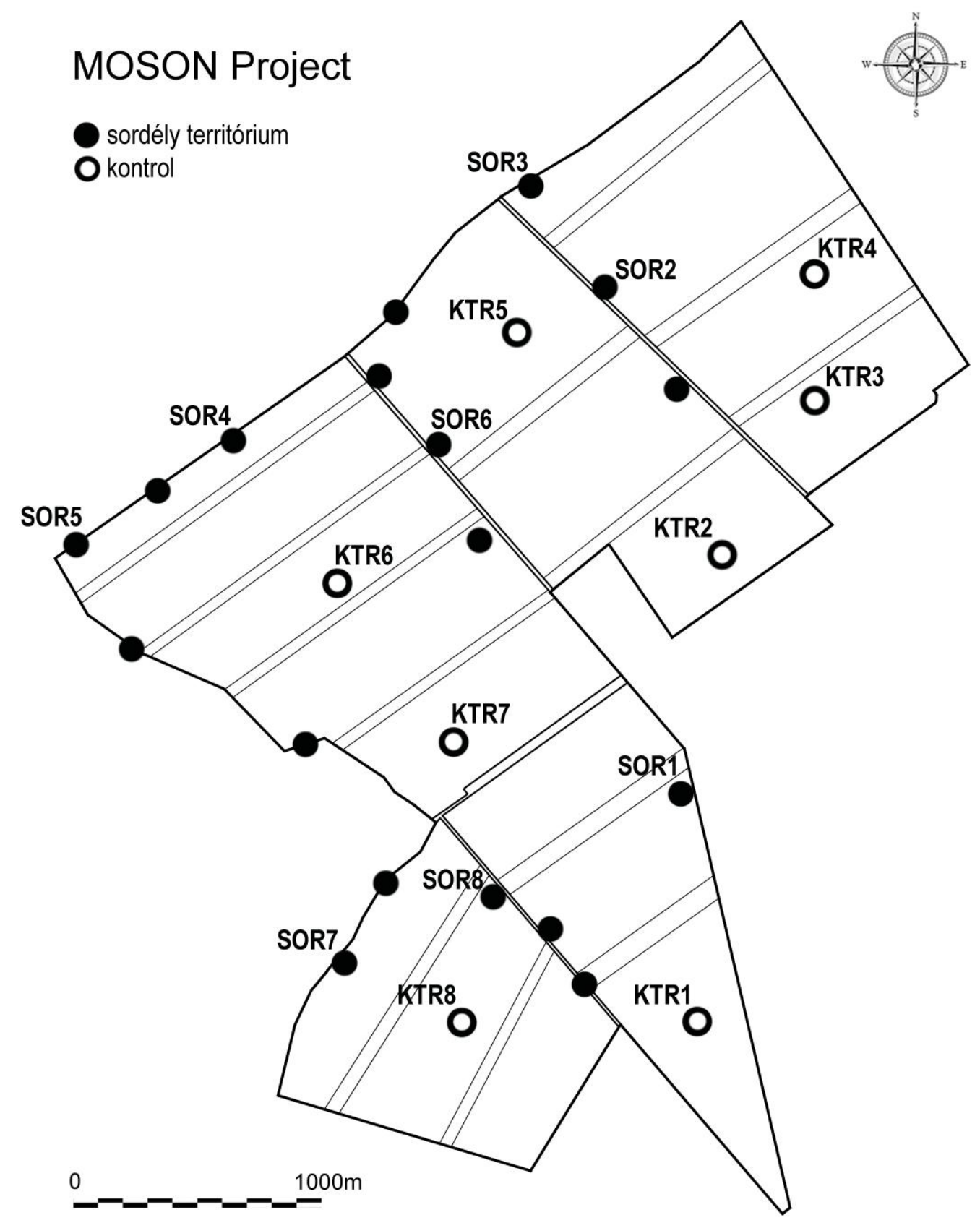

1. térkép: A felmért illetve további vizsgálatokba vont sordély territóriumok (SOR1-8) és kontrollpontok (KTR1-8)

Map 1: Corn bunting territories surveyed; territories (SORI-8) and control plots (KTRI-8) selected for further analysis 
A füfélék közül csaknem mindegyik területen elöfordult, és a területek többségén jelentős borítást ért el a franciaperje (Arrhenatherum elatius), a csomós ebír (Dactylis glomerata), az árva rozsnok (Bromus inermis), a közönséges tarackbúza (Elymus repens) és a fehér tippan (Agrostis stolonifera). A kisebb termetü füfélék közül föként a fedélrozsnok (Bromus tectorum), az angolperje (Lolium perenne), a barázdált csenkesz (Festuca rupicola) és a földre simuló hajtású vékony egércsenkesz (Vulpia myuros) volt domináns.

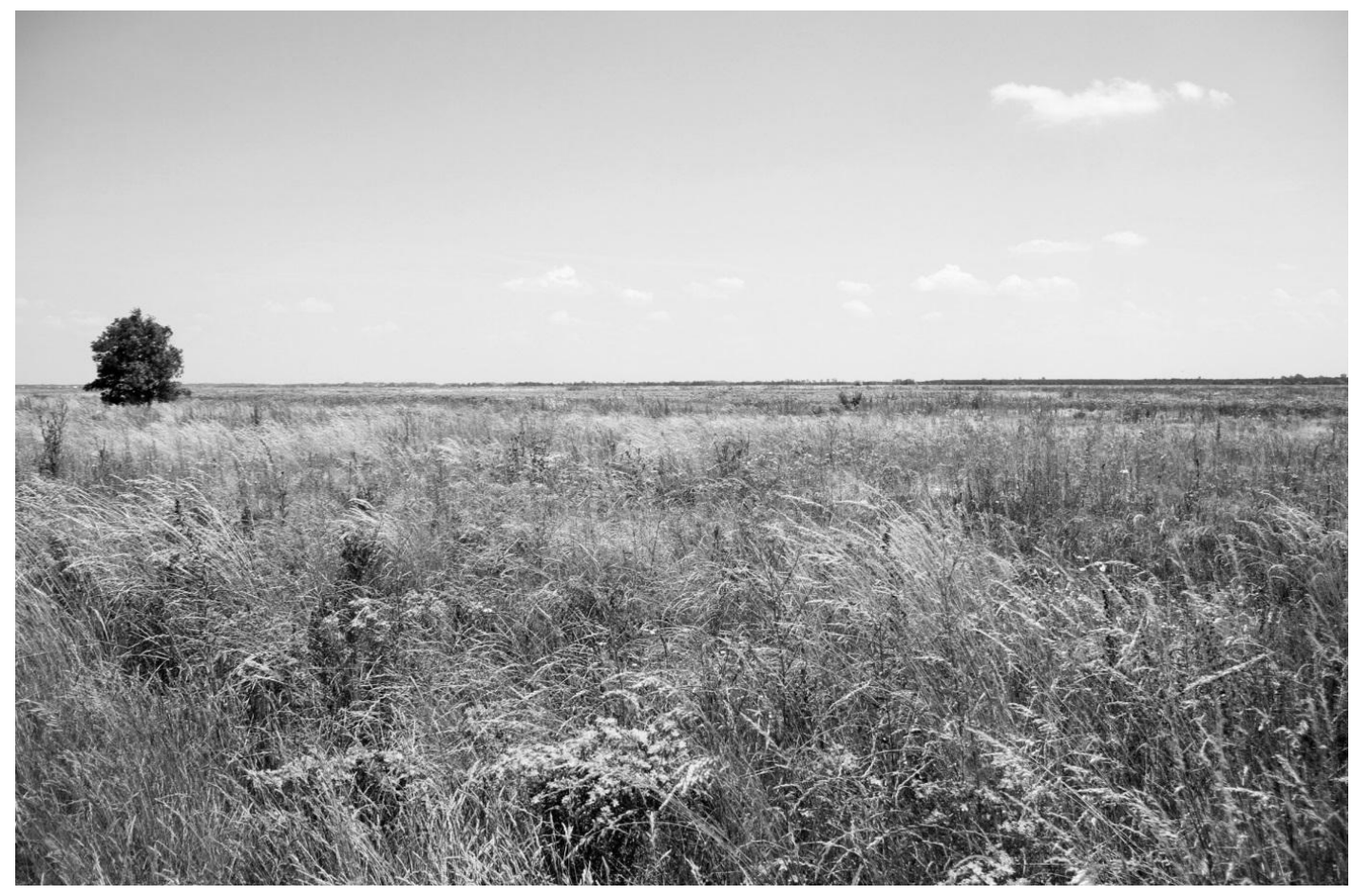

3. ábra: Jellegzetes sordélyélőhely (Fotó: Varga Sz.)

Figure 3: Typical Corn Bunting habitat (Photo: Sz. Varga)

A kétszikűek közül a közönséges orbáncfü (Hypericum perforatum) volt a territóriumok leggyakoribb és legdominánsabb faja. E fajon kívül csak a parlagi pipitér (Anthemis arvensis), a kis szeplölapu (Cerinthe minor) és egy mintaterületen a magas aranyvessző (Solidago gigantea) alkotott nagyobb foltokat. A szegélyekben változó egyedszámban, de minden esetben előfordultak a sordély számára megfelelő kiülőhelyet biztosító nagytermetű kétszikű fajok, mint például a terjőke kígyószisz és az útszéli bogáncs.

\subsection{A SORDÉLY TERRITÓRIUMOK ÉS A KONTROLLTERÜLETEK ÖSSZEHASONLÍTÓ ELEMZÉSE}

\subsubsection{Hasonlósági elemzés a botanikai felvételek alapján}

A sordély territóriumok és kontrollterületek hasonlóságát a botanikai felmérés adatait felhasználva a Jaccard és a Bray-Curtis indexen alapuló hierarchikus cluster-analízis szemlélteti (4.a-b. ábra). Csak a fajazonosságot figyelembe véve (Jaccard), a dendrogramon megfigyelhetően több kontrollterület is a sordély territóriumokkal azonos alcsoportba sorolódott (4.a. ábra). Ez azt mutatja, hogy a vetett gyepek fajkészlete a szegélyterületekéhez mutat némi hasonlóságot. Az egyes fajok borítását is figyelembe vevő Bray-Curtis módszer alapján viszont a sordély territóriumok és a kontrollterületek határozott elkülönülést mutatnak (4.b. ábra). 

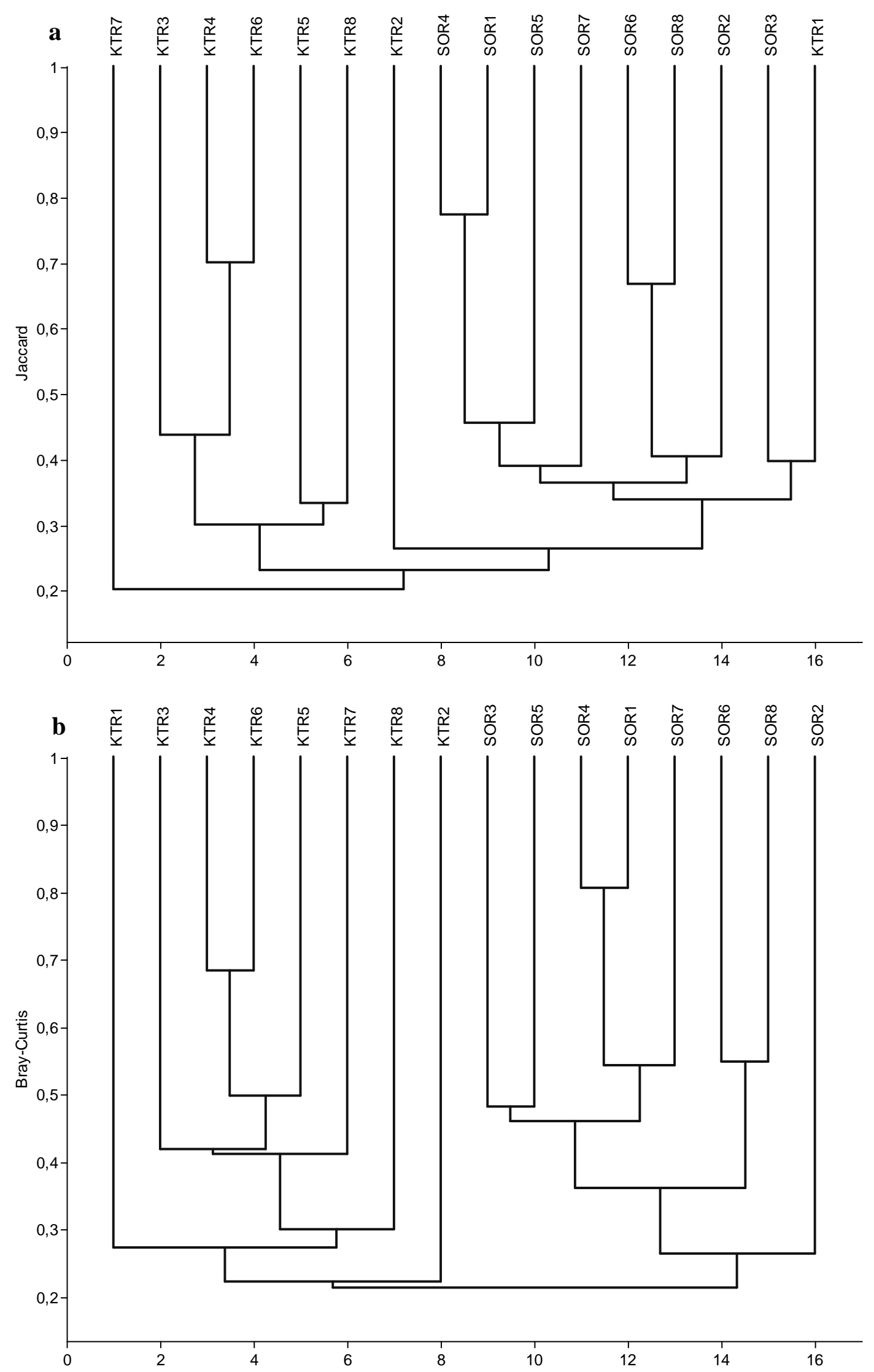

4. ábra: Jaccard (a) és Bray-Curtis (b) hasonlósági indexen alapuló hierarchikus cluster-analízis dendrogramja

Figure 4: Dendrogram based on cluster analysis using Jaccard (a) and Bray-Curtis (b) indices of similarity 


\subsubsection{Táplálék-kínálat}

A Barber-féle talajcsapda, valamint a rovarszívó együttes alkalmazásával szélesebb spektrumban sikerült megvizsgálni táplálék-kínálatot mind a tényleges sordély territóriumokban (5. és 7. ábra), mind pedig a random kontroll plotokban (6. és 8. ábra).

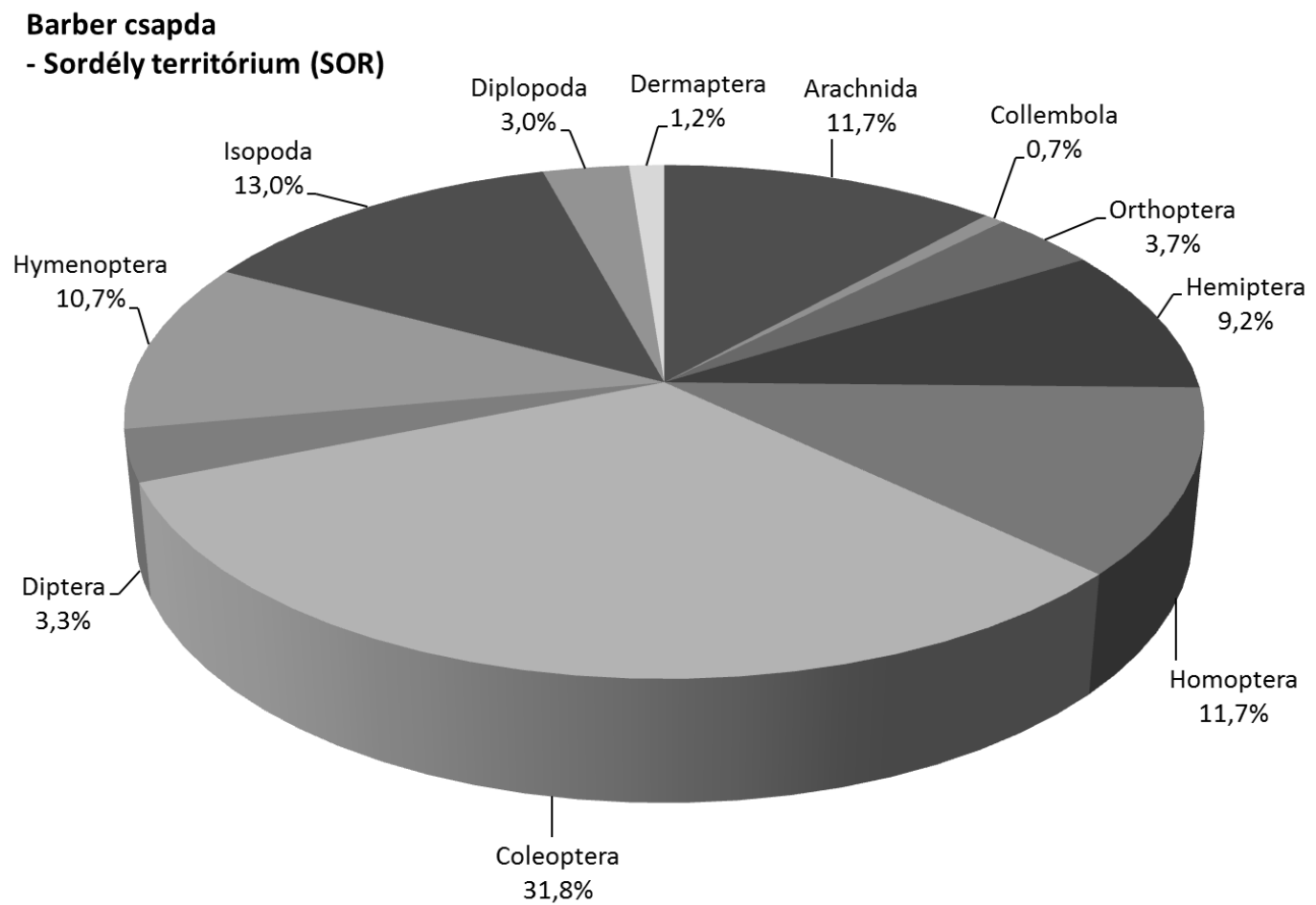

5. ábra: Állati táplálékforrás megoszlása egyedszám alapján (Barber)-Sordély territóriumok (SOR)

Figure 5: Proportion of available animal food based on the number of specimen (Barber) - Corn bunting territories (SOR)

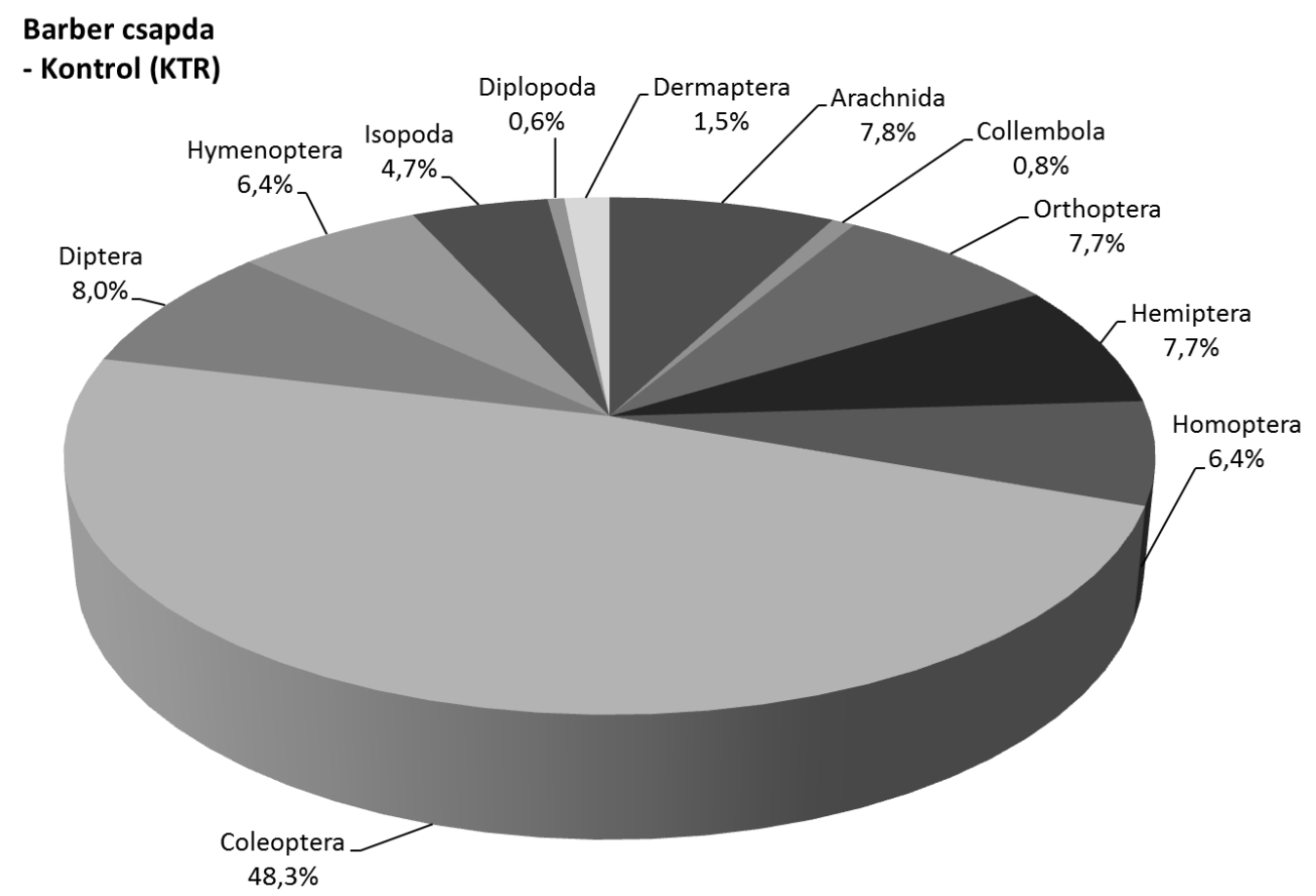

6. ábra: Állati táplálékforrás megoszlása egyedszám alapján (Barber) - Kontrollterületek (KTR)

Figure 6: Proportion of available animal food based on the number of specimen (Barber trap)-Control plots (KTR) 
A Barber csapda eredményeit összehasonlítva a rovarszívóval gyüjtött állatokkal, feltünő a bogarak (Coleoptera) nagyobb részaránya, de olyan taxonok képviselöi is előfordultak (Diplopoda, Dermaptera), amelyeket a rovarszívóval nem gyüjtöttünk.

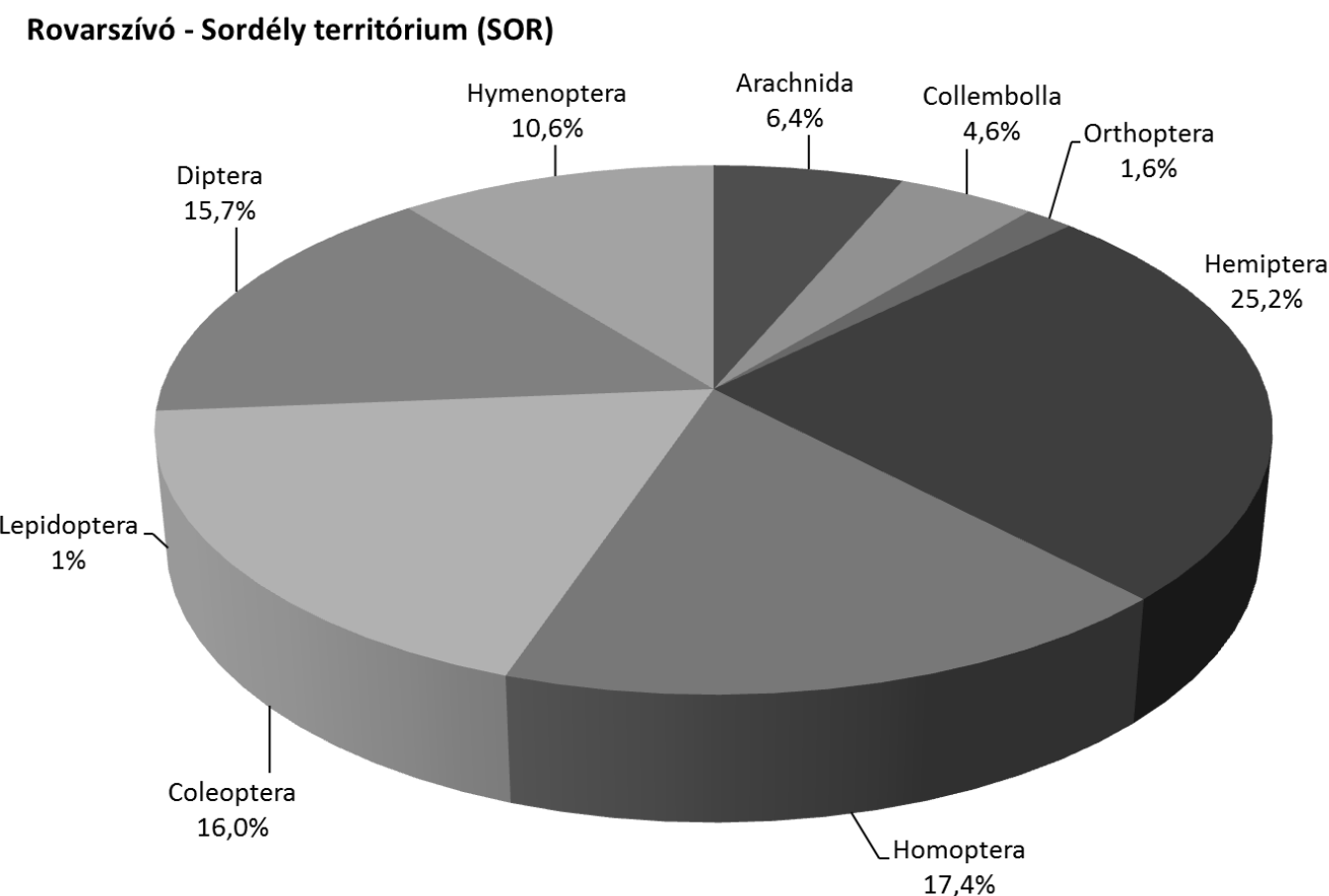

7. ábra: Állati táplálékforrás megoszlása egyedszám alapján (rovarszívó) - Sordély territóriumok (SOR)

Figure 7: Proportion of available animal food based on specimen number (vacuum sampler)-Corn bunting territories (SOR)

Rovarszívó - Kontrol (KTR)

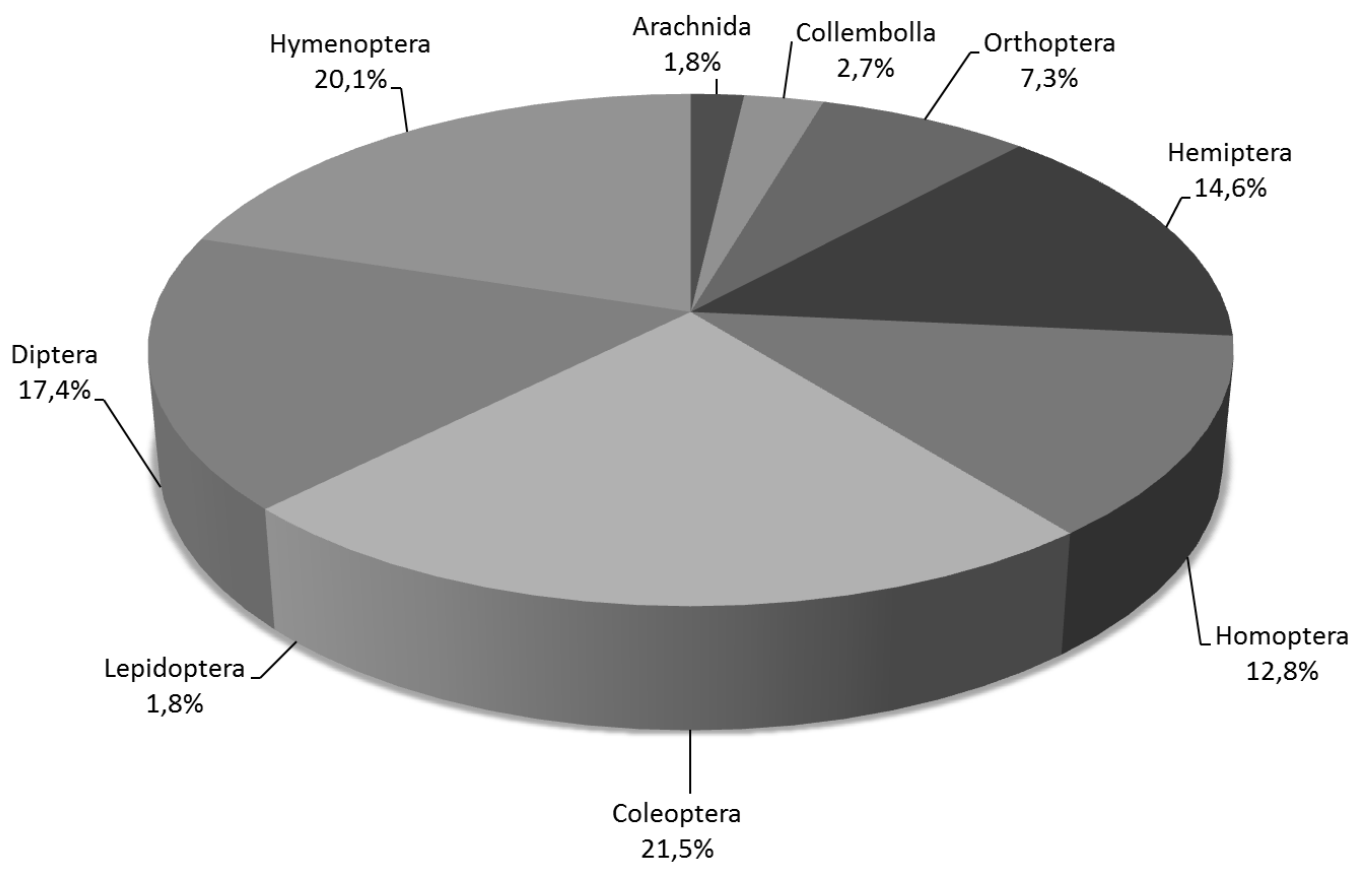

8. ábra: Állati táplálékforrás megoszlása egyedszám alapján (rovarszívó) - Kontrollterületek (KTR)

Figure 8: Proportion of available animal food based on specimen number (vacuum sampler) - Control plots (KTR) 
Mindkét gyüjtési módszer esetében megfigyelhető, hogy a sordély territóriumokban (szegélyélőhelyek) nagyobb volt a pókszabásúak (Arachnida) és a félfedelesszárnyúak (Hemiptera) aránya, míg például az egyenesszárnyúak aránya (Orthoptera) olykor a táblák belsejében, a kontrollterületeken volt nagyobb. Összességében elmondható, hogy a változatos rovartáplálék áll rendelkezésre mind a szegélyterületeken, mind a táblák belseje felé haladva is, így táplálékszerzésre nem kizárólag a szegélyélőhelyeket használja a sordély. Kétség kívül azonban a szegélyekben nagyobb biomassza tömegü rovartáplálék található, amelynek következtében a madár sokszor a kiülöhelye közvetlen körzetében vadászik pókokra, poloskákra, lepkehernyókra.

\subsubsection{Főkomponens analízis (PCA)}

A fökomponens analízis eredményeként három olyan változó jött létre, melynek a sajátértéke 1,000-nál nagyobb. A három komponens a teljes varianciának a 83,7\%-át magyarázza, amely a vizsgálat szempontjából megfelelö (3. táblázat).

\section{3. táblázat: A komponensekhez tartozó sajátértékek és a teljes varianciának a komponensekkel} magyarázott hányadai

Table 3: Eigenvalues of components and total variance explained by components

\begin{tabular}{|c|c|c|c|c|c|c|c|c|c|}
\hline \multirow[b]{2}{*}{ PC } & \multicolumn{3}{|c|}{$\begin{array}{l}\text { Kezdeti sajátértékek } \\
\text { Initial eigenvalues }\end{array}$} & \multicolumn{3}{|c|}{$\begin{array}{l}\text { Főkomponensek elöállításakor } \\
\text { Extraction sums of squared loadings }\end{array}$} & \multicolumn{3}{|c|}{$\begin{array}{c}\text { Elforgatás után } \\
\text { Rotation sums of squared loadings }\end{array}$} \\
\hline & $\begin{array}{l}\text { Teljes } \\
\text { Total }\end{array}$ & $\begin{array}{c}\text { A varian- } \\
\text { cia \%-ában } \\
\text { \% of } \\
\text { variance }\end{array}$ & $\begin{array}{l}\text { Kumulatív \% } \\
\text { Cumulative \% }\end{array}$ & $\begin{array}{l}\text { Teljes } \\
\text { Total }\end{array}$ & $\begin{array}{c}\text { A varian- } \\
\text { cia \%-ában } \\
\% \text { of } \\
\text { variance }\end{array}$ & $\begin{array}{l}\text { Kumulatív \% } \\
\text { Cumulative \% }\end{array}$ & $\begin{array}{l}\text { Teljes } \\
\text { Total }\end{array}$ & $\begin{array}{c}\text { A varian- } \\
\text { cia \%-ában } \\
\% \text { of } \\
\text { variance }\end{array}$ & $\begin{array}{l}\text { Kumulatív \% } \\
\text { Cumulative \% }\end{array}$ \\
\hline 1 & 2,995 & 33,278 & 33,278 & 2,995 & 33,278 & 33,278 & 2,951 & 32,789 & 32,789 \\
\hline 3 & 1,784 & 19,827 & 83,741 & 1,784 & 19,827 & 83,741 & 1,830 & 20,330 & 83,741 \\
\hline 4 & 0,852 & 9,465 & 93,205 & & & & & & \\
\hline 5 & 0,513 & 5,700 & 98,906 & & & & & & \\
\hline 6 & 0,064 & 0,710 & 99,616 & & & & & & \\
\hline 7 & 0,035 & 0,384 & 100,000 & & & & & & \\
\hline
\end{tabular}

Elöállítási eljárás: Principal Component Analysis.

A kiválasztott három komponens varimax ortogonális forgatással kapott együtthatóit az 4. táblázat tartalmazza. A főkomponens-együtthatók úgy is értelmezhetők, mint a mért változók és a fökomponensek közötti korrelációs együtthatók.

Látható, hogy az 1. főkomponens (PC1) leginkább a mintaterületek növényzetéhez kötődő változókat (fajszám, Shannon-diverzitás, magassági diverzitás) tartalmazza nagy súllyal. Az átlagos fökomponens-szkórok szignifikáns különbséget mutattak a tényleges territóriumok és a kontroll mintakörök között (Mann-Whitney $U$ teszt; $U=6, p<0,01$ ).

A 2. fökomponenst (PC2) leginkább a táplálék-kínálathoz kötődő változók határozzák meg: nagy súllyal szerepelnek mind a Barber-csapda, mind pedig a rovarszívós gyüjtés alapján vett egyedszámok (F_NBar, F_NVac), valamint száraztömegek (F_WBar, F_WVac) is. Az átlagos fókomponens-szkórok ebben az esetben is szignifikáns eltérést mutattak a territóriumok és a kontrollterületek között (Mann-Whitney $U$ teszt; $U=2, p<0,01$ ).

A 3. fökomponenst (PCA3) legföképpen a foltosság (Patch) határozza meg, ez a változó szerepel a legnagyobb súllyal. A főkomponens-szkórok átlagai szignifikáns eltérést mutattak a territórium és a kontroll pontok között (Mann-Whitney $U$ teszt; $U=4, p<0,01$ ). 
4. táblázat: A komponens-együtthatók mátrixa varimax forgatás után; átlagos főkomponensszkórok a tényleges territóriumoknál és a kontroll pontoknál

Table 4: Varimax rotated component matrix; mean of component scores of corn bunting territories and control plots

\begin{tabular}{lccc}
\hline & \multicolumn{3}{c}{ Component } \\
\cline { 2 - 4 } & PC1 & PC2 & PC3 \\
\hline PL_S & $\mathbf{- , 6 9 7}$ &,- 189 &, 270 \\
PL_Div & $\mathbf{, 8 3 6}$ &,- 326 &, 085 \\
PL_Nat &,- 396 &, 249 &,- 598 \\
PL_HDiv & $\mathbf{, 9 4 3}$ &,- 004 &,- 007 \\
Pacth &,- 279 &,- 241 & $\mathbf{8 6 6}$ \\
F_NBar &,- 201 & $\mathbf{, 9 1 6}$ &,- 003 \\
F_WBar &, 324 & $\mathbf{, 8 8 3}$ &,- 238 \\
F_NVac &, 345 & $\mathbf{, 7 7 4}$ &, 387 \\
F_WVac &, 277 & $\mathbf{, 7 2 9}$ &, 178 \\
\hline & \multicolumn{3}{c}{ átlag \pm SD } \\
Territórium & $2,732 \pm 1,919$ & $2,802 \pm 3,509$ & $5,809 \pm 3,629$ \\
Kontroll & $0,106 \pm 1,297$ & $-0,064 \pm 0,998$ & $-0,279 \pm 0,999$ \\
\hline
\end{tabular}

\section{DISZKUSSZIÓ}

A sordély állománycsökkenése Európa-szerte megfigyelhető, legdrasztikusabban a kontinens észak-nyugati részén (DONALD et al., 1994, TUCKER \& HEATH, 1994, EISLÖFFEL, 1997, BRICKLE et al., 2000, WATSON et al., 2009, PERKINs et al., 2011, BiRdLIFE INTERNATIONAL, 2014). Magyarországi állománycsökkenéséről már a XX. század első felében is beszámoltak (SCHENK, 1930, BÁRSONY, 1934), az ezt követő erőteljes mezőgazdasági intenzifikáció pedig valószínüsíthetően tovább csökkentette a sordély állományait.

Hazai állománytrendjéről keveset tudunk, recens felmérések jelenlét-hiány adatai csak a nyugat-dunántúli régióból állnak rendelkezésre (WINKLER, 2012). Míg az MME NOMENCLATOR BIZOTTSÁG (2008) emelkedő tendenciáról számol be, a BiRDLIFE INTERNATIONAL (2014) legújabb beszámolói a faj mérsékelt (20-49\%) állománycsökkenését jelzi hazánkból. A MOSON projekt ideális élőhelyet jelent a fajnak, ennek ellenére, mindössze 0,21 pár/10ha denzitást sikerült kimutatnunk (18 állandó pár a 880 ha projekt területen). Összevetésképpen álljon itt BÁRSONY (1955) megfigyelése, miszerint a Borsod megyei Hejőszalonta község határában, 150 méteren belül 18 lakott, tojásos sordély fészket sikerült felfedezni.

A MOSON Projekben végzett vizsgálatok kimutatták, hogy a sordély egyértelműen a gyepes táblaszegélyeket választotta, itt álltak rendelkezésre megfelelö kiülöhelyek, éneklöpontok, amelyek gyakorisága a táblák belsejében jelentősen kisebb. ERDŐs és munkatársai (2007) a Mindennapi Madaraink Monitoringja adatbázisa alapján kimutatták, hogy a sordély a természetes gyepeket csak akkor részesítette elönyben, ha a szegélyükben sem fordultak elő fák és cserjék. A MOSON Project területén végzett kisebb léptékü vizsgálataink ennek ellentmondanak, hiszen a vizsgálati területen a magános cserjéket, kisebb termetü fákat (gyepürózsa, fekede bodza, mezei szil) kimondottan preferálta a faj, kiülőhelynek, éneklőpontnak használva azokat. Ezt támasztotta alá a főkomponens-analízis (PCA) is, miszerint a vegetáció magassági struktúrájának diverzitása hatással van a sordélyok habitatválasztására. JÁNOSKA (2011) kisalföldi erdősávokban (LAJTA Project) végzett kutatásaiban beszámol a faj jelenlétéről az erdősávok szegélyében is. A MOSON projektben azt tapasztaltuk, hogy a sordély az erdősávokat (beleértve azok szegélyterületeit) kerülte, 
kizárólag a gyepes táblaszegélyekben fordult elő. Ez azonban magyarázható a két projektterület mezővédő erdősávjainak vegetációszerkezetbeli eltéréseivel is.

$\mathrm{Az}$ egyetlen megtalált fészek szintén a kiülőhelyként, éneklőpontként is használt gyepes táblaszegély közelében volt, mindössze 18 méterre a földúttól. A szegélyekben a gyomfajok diverzitása magasabb, így változatosabb táplálékot talál itt a madár, mint a táblák belsejében (DONALD \& EvAns, 1995, CRAMP \& PERRINS, 1994, GluTZ VON BLOTZHEIM \& BAUER, 1997). Az ízeltlábú táplálékkínálatra irányuló vizsgálatok azt mutatták, hogy a sordély által leginkább preferált pókszabásúak (Arachnida) és a félfedelesszárnyúak (Hemiptera) szintén a szegélyekben dúsulnak fel, míg a kisebb arányban fogyasztott, nagyobb testü bogarak (Coleoptera) aránya a táblák belseje felé haladva volt nagyobb. A növényzeti struktúra mellett ez is fontos szerepet játszik a sordélyok szegélyekben való megtelepedésében (STOATE et al., 2000, WINKLER et al., 2012).

A MOSON Project területén lényegesen kevesebb veszélyeztető tényezővel kell számolnunk, mint egy intenzíven kezelt mezőgazdasági területen. A túzokbarát gazdálkodás a célfaj mellett számos más, agrárkörnyezetben élő mezei madárfajnak is kedvező (pl. fácán Phasianus colchicus, fogoly, énekesmadarak). A részben vetett, ugar-jellegű táblák, a vegyszermentes táblaszegélyek a sordély megtelepedéséhez és eredményes fészkeléséhez nagyban hozzájárulnak.

Problémát jelent viszont a területen a kaszálás, amely sokszor már június végén-július elején megkezdődik. Ez az időszak számos földön fészkelő énekesmadár, például a mezei pacsirta (Alauda arvensis), sárga billegető (Motacilla flava), cigánycsuk (Saxicola rubicola), rozsdás csuk (Saxicola rubetra), hantmadár (Oenanthe oenanthe) valamint a sordély második költésének ideje, így ezen fészekaljak nagyarányú pusztulása valószínüsíthető (BIRCKLE et al., 2000, BROYERA et al., 2014, STREBEL et al., 2015). Megkérdőjelezhető ezen felül a terület cél-faja, a túzok (Otis tarda) csibéinek túlélése is, hiszen ebben az időszakban még nehezen kapnak szárnyra, a gyorsan, sokszor vadriasztó lánc nélkül közlekedő gépek így fokozott veszélyt jelentenek e fajra nézve is.

Számos európai tanulmány kimutatta, hogy a kaszálások idejének eltolása a sordély, és számos más földön fészkelö faj költésének eredményességét nagymértékben növelheti (PERKINS et al., 2008, 2013, BROYERA et al., 2014), ezért legfőbb javaslatként a kaszálások ütemtervének átgondolása jelölhető meg.

\section{KÖSZÖNETNYILVÁNÍTÁS}

Köszönjük ERDŐ ÁDÁMnak a terepi munka során nyújtott segítségét. A kutatás az AGRÁRKLÍMA.2 VKSZ_12-1-2013-0034 pályázati projekt támogatásával valósult meg.

\section{IRODALOMJEGYZÉK}

BÁRSONY GY. (1934): A sordély megfogyatkozása Borsod megyében. Aquila 38-41: 396-397.

BÁRSONY Gy. (1955): Sordély „telepes” fészkelése. Aquila 59-62: 397, 449.

BENTON, T.G., VICKERY, J.A. \& WILSON, J.D. (2003): Farmland biodiversity: is habitat heterogeneity the key? Trends in Ecology \& Evolution 18: 182-188.

http://dx.doi.org/10.1016/S0169-5347(03)00011-9 
BEYER, H.L. (2004): Hawth's analysis tools for ARCGIS. In: BLOUIN-DEMERS, G. \& WEATHERHEAD, P.J. (eds.): Thermal Ecology of Black Rat Snakes (Elaphe obsoleta) in a Thermally Challenging Environment. Ecology 82: 3025-3043. http://dx.doi.org/10.1890/0012-9658(2001)082[3025:TEOBRS]2.0.CO;2

BIRDLIFE INTERNATIONAL (2014): Miliaria calandra. The IUCN Red List of Threatened Species 2014: e.T22721020A62543360

BORHIDI A. (1993): A magyar flóra szociális magatartás típusai, Természetességi és relatív ökológiai értékszámai. A Környezetvédelmi és terület fejlesztési Minisztérium Természetvédelmi Hivatala és a Janus Pannonius Tudományegyetem Kiadványa, Pécs, 93 pp.

BRAUN-BLANQUET, J. (1928): Pflanzensoziologie. Grundzüge der Vegetationskunde. Springer, Berlin, $330 \mathrm{p}$.

BRAY, J.R. \& CURTIS, J.T. (1957): An ordination of the upland forest communities of southern Southern Wisconsin. Ecological Monographs 27: 325-349. http://dx.doi.org/10.2307/1942268

BRICKLE, N.W., HARPER, D.G.C., AEBISCHER, N.J. \& COCKAYNE, S.H. (2000): Effects of agricultural intensification on the breeding success of corn buntings Miliaria calandra. Journal of Applied Ecology 37: 742-755. http://dx.doi.org/10.1046/j.1365-2664.2000.00542.x

Broyera, J., Sukhanovab O. \& MischenKob, A. (2014): Mowing management and density dependence in meadow passerine hatching success. Bird Study 61(3): 394-403. http://dx.doi.org/10.1080/00063657.2014.925847

CRAMP, S. \& PERRINS, C.M. (1994): The Birds of the Western Palearctic Volume IX. Oxford University Press, Oxford, New York, 488 p.

Donald, P.F. \& AEBISCHER, N.J. (eds.) (1997): The Ecology and Conservation of Corn Buntings (Miliaria calandra). Joint Nature Conservation Committee, Peterborough, UK.

DonALD, P.F. \& EVANS, A.D. (1995): Habitat selection and population size of Corn Buntings Miliaria calandra breeding in Britain. Bird Study 42: 190-204. http://dx.doi.org/10.1080/00063659509477168

DONALD, P.F., WILSON, J.D. \& SHEPHERD, M. (1994): The decline of the corn bunting. British Birds 87: $106-132$.

DÖVÉNYI Z. (szerk.) (2010): Magyarország kistájainak katasztere. MTA Földrajztudományi Kutatóintézet, Budapest.

EISLÖFFEL, F. (1997) The corn bunting Miliaria calandra in south-west Germany: population decline and habitat requirements. The Corn Bunting (Miliaria calandra) in South-West Germany: Population Decline and Habitat Requirements. In: DonALD, P.F. \& AEBISCHER, N.J. (eds.): The Ecology and Conservation of Corn Buntings (Miliaria calandra). Joint Nature Conservation Committee, Peterborough, UK, 170-173.

ERDÖS S., SzÉP T., BÁLDI A. \& NAGY K. (2007): Mezőgazdasági területek felszínborításának és tájszerkezetének hatása három madárfaj gyakoriságára. Tájökológiai Lapok 5(1): 161-172.

FARAGÓ S. (2006): A túzok védelme Magyarországon, Life Nature Project 2005. évi monitoring jelentése. Magyar Apróvad Közlemények, 2006. évi különszám: 12-15.

GLUTZ VON BLOTZHEIM, U.N. \& K.M. BAUER (1997): Handbuch der Vögel Mitteleuropas, Bd. 14/III: Passeriformes (5. Teil): Emberizidae - Icteridae. Aula-Verlag, Wiesbaden.

HAMMER, Ø., HARPER, D.A.T. \& P.D. RYAN (2001): PAST: Paleontological Statistics Software Package for Education and Data Analyasis. Palaentologia Electronica 4(1): 9 p.

HorvÁth F., DOBOlYi Z.K., MORSChHAUSER T., LÖKÖS K., KARAS L. \& SZERDAHELYI T. (1995): Flóra adatbázis. 1.2. Taxonlista és attribútum-állomány. FLÓRA munkacsoport, MTM Növénytára, Vácrátót: 141-196.

Inger, R., Gregory, R., Duffy, J.P., Stott, I., VoriseK, P. \& GASTON, K.J. (2015): Common European birds are declining rapidly while less abundant species' numbers are rising. Ecology Letters 18(1): 28-36. http://dx.doi.org/10.1111/ele.12387

JACCARD, P. (1901): Étude comparative de la distribution florale dans une portion des Alpes et des Jura. Bulletin de la Société Vaudoise des Sciences Naturelles 37: 547-579. http://dx.doi.org/10.5169/seals-266450 
JÁNOSKA F. (2011): Fészkelő madárállományok monitoringja erdősávokban. Ornis Hungarica 19: $125-132$.

KÁDÁR F. \& SAMU F. (2006): A duplaedényes talajcsapdák használata Magyarországon. Növényvédelem 42(6): 305-312.

KIRÁLY G. (szerk.) (2009): Új magyar füvészkönyv. Magyarország hajtásos növényei. Határozókulcsok. Aggteleki Nemzeti Park Igazgatóság, Jósvafő, 616 p.

KOVÁCS A., BATÁRY P. \& BÁLDI A. (2007): Különböző intenzitással kezelt szántóföldek madár és növény fajszámának és abundanciájának összehasonlítása. Természetvédelmi Közlemények 13: 371-378.

MÁRKUS F. (1998): Sordély (Miliaria calandra). In: HARASZTHY L. (szerk.): Magyarország madarai. Mezőgazda Kiadó, Budapest, 389 p.

MichIE, M.G. (1982): Use of the Bray-Curtis similarity measure in cluster analysis of foraminiferal data. Mathematical Geology 14(6): 661-667. http://dx.doi.org/10.1007/BF01033886

MME NOMENCLATOR BIZOTTSÁG (2008): Magyarország madarainak névjegyzéke. Nomenclator Avium Hungariae. Magyar Madártani és Természetvédelmi Egyesület, Budapest, 278 p.

NIE, N.H., Hull, C.H., JeRKINS, J.G., StEINBRENNER, K. \& BENT, D.H. (1975): SPSS: Statistical Package for the Social Sciences. 2. edition. MeGraw-Hill Inc., New York, 675 p.

Perkins, A.J., Maggs, H.E., Watson, A. \& Wilson, J.D. (2011): Adaptive management and targeting of agri-environment schemes does benefit biodiversity: a case study of the corn bunting Emberiza calandra. Journal of Applied Ecology 48: 514-522. http://dx.doi.org/10.1111/j.1365-2664.2011.01958.x

Perkins, A.J., MAGgS, H.E., WiLson J.D. \& WATSON A. (2013): Delayed mowing increases corn bunting Emberiza calandra nest success in an agri-environment scheme trial. Agriculture, Ecosystems and Environment 181: 80-89. https://doi.org/10.1016/j.agee.2013.09.010

Perkins, A.J., Maggs, H.E., WiLson, J.D., Watson, A. \& SMOUT, C. (2008): Targeted management intervention reduces rate of population decline of corn buntings Emberiza calandra in eastern Scotland. Bird Study 55: 52-58. http://dx.doi.org/10.1080/00063650809461504

SCHENK H. (1930): A sordély rohamos megfogyatkozása Óverbászon. Aquila 36-37: 331-332.

Siriwardena, G.M., BAILlie, S., Buckland, S., Fewster, R., MARCHANT, J. \& Wilson, J. (1998): Trends in the abundance of farmland birds: a quantitative comparison of smoothed Common Birds Census indices. Journal of Applied Ecology 35(1): 24-43.

http://dx.doi.org/10.1046/j.1365-2664.1998.00275.x

SPSS (1999): SPSS Base 10.0. SPSS Incorporation, Chicago.

StOATE, C., R. BorRAlHo \& ARAUjo M. (2000): Factors affecting corn bunting Miliaria calandra abundance in a Portuguese agricultural landscape. Agriculture, Ecosystems and Environment 77: 219-226. https://doi.org/10.1016/S0167-8809(99)00101-2

Strebel, G., JACOT, A., HORCH, P. \& SPAAR, R. (2015): Effects of grassland intensification on Whinchats Saxicola rubetra and implications for conservation in upland habitats. Ibis 157(2): 250-259. http://dx.doi.org/10.1111/ibi.12250

SUTHERLAND, W. J. (2002): Openness in management. Nature 418: 834-835. https://doi.org/10.1016/j.biocon.2008.06.023

TUCKER, G.M. \& HEATH, M.F. (1994): The Conservation Status of European Birds. ICBP, Cambridge, $600 \mathrm{p}$.

Verhulst, J., BÁLDI, A. \& KLEIJN, D. (2004): Relationship between land-use intensity and species richness and abundance of birds in Hungary. Agriculture, Ecosystems and Environment 104: 456-473. https://doi.org/10.1016/j.agee.2004.01.043

Watson, A., Perkins, A.J., Maggs, H.E. \& Wilson, J.D. (2007): Decline of Corn Buntings Emberiza calandra on east Scottish study areas in 1989-2007. Bird Study 56(2): 213-220. http://dx.doi.org/10.1080/00063650902792072

WINKLER D. (2012): Sordély (Emberiza calandra). In: FARAGÓ S. (szerk.): Nyugat-Magyarország fészkelő madarainak elterjedési atlasza. Nyugat-magyarországi Egyetem Kiadó, Sopron, 223. 
WiNKLER D., ERDÖ Á. \& HARTA I. (2012): Comparative analysis of breeding bird communities in different open agricultural habitats, Lajta Project, Western Hungary. In: NEMÉNYI, M. \& HEIL, B. (eds.): International Scientific Conference on Sustainable Development and Ecological Footprint: The Impact of Urbanization, Industrial and Agricultural Technologies on the Natural Environment. Sopron, 26-27. March 2012. p. 1-4.

WretenberG, J., Lindström, A., Svensson, S., Thierfelder, T. \& PART, T. (2006): Population trends of farmland birds in Sweden and England: similar trends but different patterns of agricultural intensification. Journal of Applied Ecology 43(6): 1110-1120. http://dx.doi.org/10.1111/j.1365-2664.2006.01216.x 